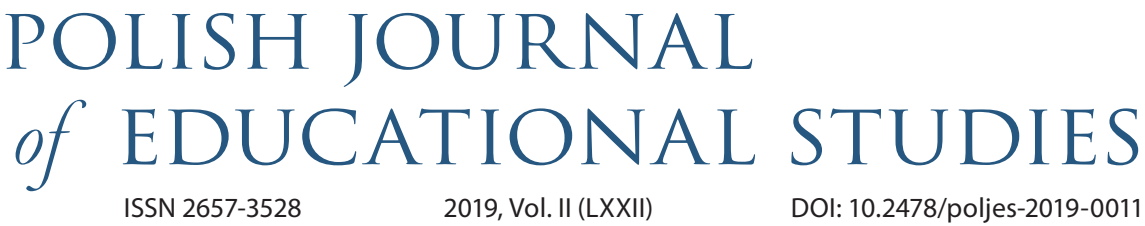

\title{
Cross-cultural Education in the Formation of Supranational Communal Competence
}

\author{
Jerzy Nikitorowicz'
}

\begin{abstract}
The text presents the assumptions of cross-cultural education, emphasizing that in the multicultural world it is necessary to look for solutions used in the past as regards the formation and functioning of supranational communities. The author believes that currently, in light of increasing nationalisms, cross-cultural competence that enables the formation of supranational communities is indispensable.

He points out that we should refer to the tradition of the Commonwealth of many nations in this respect. He considers the functioning of the Polish-Lithuanian Commonwealth, experiences of the multicultural policy of that time, where other nations were treated with appreciation and respect, as something that should be accomplished by contemporary cross-cultural education. He highlights the need to draw on that multicultural experiment, to reflect on it and analyze it in order to realize the essence of tradition of civil liberties and relationships between free people and communities based on freedom.
\end{abstract}

\section{KEY WORDS:}

cross-cultural education, culture, nation, community, cross-cultural competence, Polish-Lithuanian Commonwealth

One of the problems of the contemporary world is the need to find out how to understand and communicate with people of different nationalities, and to learn to use the achievements of various nations, not only those functioning in close proximity. However, these closest nations are the ones we need to begin with, e.g., when cultivating the myth of the Sarmatian origin of all the nobility, which became an important factor of community and consolidated its coherence, determining its ideology, the system of values, political culture and customs. In this concept, Slavs were supposed to have

1 Faculty of Education, University of Bialystok, Poland E-MAIL: j.nikitorowicz@uwb.edu.pl ORCID: 0000-0003-4371-8322 
originated from bold ancient Sarmatians inhabiting the area between the Sea of Azov and the Don River. Then, only the nobility, regardless of their language or ethnicity, were regarded as the descendants of Sarmatians. Lithuanian nobles, just like those in the Crown, believed they were the descendants of Sarmatians, although there was also a myth that Lithuanians originated from ancient Romans, French nobles from ancient Gauls, Swedish ones from Vandals and Goths, etc.

Cross-cultural education assumes the existence of culturally diverse groups, acknowledging their presence, as well as a natural need to learn about them and explain both the shared and the separate aspects of their history. These concepts are visible even in the very phrase "cross-cultural education". In the context of the foregoing, the main theses of cross-cultural education refer to initiating contacts with representatives of other nations, which is necessary to understand fully the development of our own national culture, our place in the nation, and the obligations we have towards it. Humans and their national culture function best in the conditions of diversity and ongoing encounters with representatives of other nations and their culture. Only then can they develop, be creative and innovative. Hence, I support the anthropological approach, assuming that the basic elements of human existence are gaining cross-cultural competence, creating interpersonal bonds and relations with other nations. I believe that the desire and need to perceive and discover differences, to be openminded, to learn about others and get closer to them, to understand, exchange views and cooperate are of utmost importance, allowing the person to fully understand themselves. "Experiencing the presence of You, I become able - as if by resonance - to deeply feel myself, my inner self. Full and real experience of my own life is only possible in relations with You" (Buber, 1993, p. 93). The concept of symbolic interactionism, i.e., the view that an individual forms their identity through references to the group they are part of, is evident in this approach.

Previous experiences in the analysis and research of cross-culturalism provide more and more evidence that currently, the need to study solutions from the past, which may be useful in today's multicultural world, is especially acute, because the policy applied in the management of multiculturalism in Western European countries recently definitely does not work. The strategies of assimilation, liberal approach to multiculturalism, cultural relativism, political correctness and civic integration have clearly failed.

$$
*^{*} *
$$

The presence of Poland in the Council of Europe and the European Union is naturally supposed to foster the development of supranational communal competence on the basis of Judaism, Christianity, Greek philosophy and Roman law. There are some voices, however, that say that Europeanism is exclusive and actually excludes many 
Europeans, while its members are constrained and deprived of liberty. Especially us Poles, with our traditions of fighting for political freedom and national independence, are beginning to disclose the European colonialism. More and more often we ask: How doo we find our place in a Europe from which we have been excluded? How can we be be an active members of the Union understood as a voluntary institutional product of collaboration between free nations? How do we make use of modernization and the better life offered by Europe, yet without giving up on our own cultural heritage? We seem to have forgotten that we have special opportunities to refer to the tradition of building supranational bonds with neighbors from the East, with whom we are related through the shared history of the Commonwealth of many nations.

We should begin with learning the history of that Commonwealth, analyzing the examples of building communities and developing supranational communal competence on that basis. In inter-war Poland, in the $2^{\text {nd }}$ Republic of Poland, knowledge about Lithuanians, Belarusians and Ukrainians inhabiting almost half the territory of the Polish state was very little and the relations with those nations were difficult. Currently, the accumulated problems of prejudice and stereotypes can be tackled on another plane, free from the pressures and orders of our powerful neighbors. It is possible to carry out a reliable analysis of the common cultural heritage, to sum up the strong and weak points of our situation as regards the knowledge of our neighbors' culture, plans and ambitions. The main problem seems to be how to interpret the nations' pursuits while rejecting the nationalistic approach and taking into consideration the issue of various complexes, phobias and megalomania. Our nation used to be multi-ethnic, including people of various languages and religions. Human and civil liberties, religious tolerance and the attractiveness of the Polish culture led to the Polonization of non-Polish nobility in terms of language, culture and awareness. However, foreign influences were not considered as a threat, which can be proved i.a., by the fact that the Polish national outfit worn by the nobility, "kontush", was adopted from the Turkish culture, and the bent sabre, "karabela", from the Persian one. It can be said that the elements of culture were drawn from everywhere, transformed and adapted to the Polish customs and traditions. Even in 1863, during the January Uprising, the emblem of the secret national government was a tri-sectional coat of arms representing the image of the White Eagle (Poland), "Pogon" (Lithuania) and the Archangel (Ruthenia). Up to the $20^{\text {th }}$ century, the territory of the Grand Duchy of Lithuania was a specific melting pot of several nationalities. That is why after entering with the Polish army to Vilnius in April 1919, J. Piłsudski issued the appeal To the Residents of the Former Grand Duchy of Lithuania in two languages.

A specific form of multiculturalism was created, with many languages, religions, customs and traditions, in which the initially dominant Old Ruthenian (Old Belarusian) language was gradually replaced by the slowly developing Polish tongue. Beginning 
in the $16^{\text {th }}$ century, it was more and more often used as the official language. We do not know what would have happened to it if it had not become popular and acknowledged the Commonwealth. Perhaps it would not have survived and would not have been functioning in the time of annexations, as it did despite strong Russification and Germanization since the $18^{\text {th }}$ century.

Hence, in light of blaming the state for Polonization, it is worth pointing to the functioning of languages (Lithuanian, Ruthenian and Polish) in the Polish-Lithuanian Commonwealth. This knowledge seems to be particularly important in the context of eliminating stereotypes, prejudice and myths developed over the centuries concerning the linguistic appropriation of the inhabitants of the Grand Duchy of Lithuania. After all, before the formation of nations, i.e., before the $18^{\text {th }} / 19^{\text {th }}$ century, language could not have been the main factor of national identification. Spoken (tribal, regional) languages were used along with administrative, official languages and the universal ones, such as Latin. An important element was the transition from oral forms to the written form so that, when the state was formed, the language could be used in documentation, chronicles, accounts, etc. In the early centuries of the existence of the Commonwealth, Ruthenian (Old Belarusian) served as the state language. Formally, it retained that status until 1697. Latin was used as well, and it was pointed out that Latin should be the national language of Lithuanians.

For this purpose, a Jesuit college was even established in Vilnius, and the history of Lithuania was written in Latin, promoting the theory that Lithuanians originated from Romans (Rachuba, 2010, pp. 25-38). The Latinization of Lithuania did not succeed, and Polish began to dominate in the early $17^{\text {th }}$ century. Instructions, sejmik resolutions and court deeds concerning the granting of property or nominations were written in that language. "...Until the early $18^{\text {th }}$ century, Polish had already been commonly used, even in the Eastern borderland of the country. The language became common, not only among the (Lithuanian, Ruthenian, German and Tatar) nobility, but also among the other social classes: the clergy, townspeople and even peasants...

Since 1697, Polish has been formally the official language, although in the Lithuanian central chancellery, Latin was still used as well" (Rachuba, 2010, pp. 33-34). Lithuanian still did not have a written form at that time. Later, it was used to write down collections of sermons, church hymns, catechisms etc., so it mostly served a religious function. According to Andrzej Rachuba (2010, pp. 31-32), "Among the peasant class, the two main dialects of Lithuanian (spoken in Aukštaitija and in Samogitia) were maintained, but it was soon abandoned by the nobility in their everyday speech". The Union caused the necessity to communicate in Polish, first in daily life, and then in the public life of the Jagiellonian court. It was promoted by the newcomers from the Crown who settled in the Grand Duchy: priests, merchants, clerks etc. In a slow and lasting process, Polish was becoming the national language. "Even in the $16^{\text {th }}$ century, 
the upper class of lords and princes used Polish quite well; some even treated it as the basic language, especially in families with a Lithuanian origin (e.g., the Radziwiłls), while Orthodox Ruthenians, also from the sphere of magnates, used Ruthenian even in the early $17^{\text {th }}$ century" (Rachuba, 2010, p. 33).

This briefly described process of the formation of languages in the Polish-Lithuanian Commonwealth should not be identified with the process of identity changes or national identification. People learnt and used language mostly for practical reasons and in order to achieve noble status and related privileges. It can be said that they became Poles in the meaning of living in the Polish state as the nobility, the privileged class, enjoying many liberties and rights the others did not have. Having that privilege, however, they defended the Lithuanian state sovereignty within the federation, as well as the rights to their estates, offices, the legal system, the Lithuanian statutes, symbols, traditions, customs etc.

Thus, it is difficult to unambiguously identify Lithuanians, Ruthenians, Poles or other communities. As Rachuba (2010, p. 35) points out, they made a conglomerate of multi-ethnic, multilinguistic and multireligious citizens of the Grand Duchy of Lithuania with a double or even triple sense of belonging (Lithuanian/Polish, Ruthenian/Polish, Livonian/Polish, Ruthenian/Lithuanian or Livonian/Lithuanian). The very term "a Lithuanian" did not only refer to a resident of Aukštaitija or Samogitia but also to a citizen of the GDL. The place of birth, the language spoken or religion were not the decisive factors in this respect. "The famous Polish phrase written by Mickiewicz, "Lithuania! My homeland!", reflected the sense of identity of a Lithuanian nobleman, common in the early $19^{\text {th }}$ century, even if he was of "Ruthenian" origin or had been living for centuries in the Ruthenian territories of the Grand Duchy of Lithuania" (Rachuba, 2010, p. 35).

As I have already mentioned, being Poles only in the state aspect and having settled for good in the Grand Duchy of Lithuania, they defended the interests of those lands, regarding themselves as the citizens of the GDL and the nobility of the Commonwealth. This may be evidenced by their participation in the wars against Swedes or Tsarist Russia in the $17^{\text {th }}$ century. A later problem, that arose in the $18^{\text {th }}$ century, was the responsibility for the common state. Personal needs and interests, suspicion, the lack of understanding or desire to communicate, envy and hatred on various grounds, treasons, the pursuit of profit, service for other powers and similar developments became predominant.

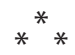

Culture inherently involves dialog, associated with understanding, agreement, consensus and a positive atmosphere. The lack of such dialog leads to isolation, marginalization, tensions, conflicts, aggression, violence and wars. Its presence, on the other hand, implicates coexistence and is treated as an imperative for ensuring and maintaining 
peace. Hence, the idea of dialogue is inherently included in cross-cultural education, referring to the mutual influences of individuals and groups of humans with the use of competencies, forces, capacities, cultural resources, experiences and abilities of individuals and groups, allowing them to develop and to become fully aware and creative, capable of active self-actualization of their own unique identity. Gaining supranational communal competence is always connected with the formation of dialogue-oriented attitudes, acquiring the skills of replacing the reaction to difference by interaction with the representatives of that difference through the elimination of negative emotions, continuous attempts to understand and explain the nature of those differences and pursuing agreement.

Only balanced emotions combined with an awareness of the value of one's own culture, behavioral patterns developed in the historical process, knowledge of authorities, values and principles of functioning and respect for one's own and other cultures allow us to gain and use in practice the specialist knowledge acquired intentionally in order to learn about new cultures, understand them and thus eliminate prejudice, stereotypes repeated from generation to generation, and avoid using them in contact with the representatives of other cultures. Therefore, in a further process it may be necessary to engage in relationships with the representatives of other cultures and take the risk of engaging in conflicts and difficult situations in order to defend and protect their value. Self-criticism concerning one's own culture and questioning a unidimensional point of reference also develop, along with the foundations of respect for diversity and intercultural identity and the principles of cooperation and collaboration.

If we want to make use of culture created in different societies, communicate with the representatives of various cultures (such as migrants, tourists, or managers of foreign companies) and collaborate in science and education, we need to do our best to develop cross-cultural competence and create supranational communities. Katarzyna Gajek (2011, p. 209), presenting various ways of understanding cross-cultural competence, points to its complementary character. "It involves a multidimensional image including lower and higher order factors. On the basic level, there are knowledge (of history, language, views of the world, savoir-vivre, tradition, social roles etc.), skills (listening, decentration, problem solving, reflectivity etc.) and motivation (self-awareness concerning ambitions, the source of motivation, one's own communication style etc.).

On the advanced level, there are such factors as creativity, criticism and moral autonomy". Therefore, in educational measures we should not only provide training, workshops and courses, but also dialogue-related skills and attitudes, because "...currently, cross-cultural competence is more important than ever, since they allow us to see and learn the reasons for some of the most acute problems of contemporary societies. Underlying phenomena such as discrimination, racism and hateful speech are cultural, socio-cultural, ethnic and other differences" (Brotto, Huber et al., 2014, p. 5). 
In the archipelago of diasporas, as pointed out by Zygmunt Bauman (2011), there is no central place, no power of the imperial world, but there is constant differentiation, the isolation of more and more elements with various scope and force. The fear of the Strangers and of engaging in their problems is increasing, so Bauman warned his readers about the coming of the era of disengagement and encouraged them to think over the problems connected with the development of culture. He pointed to many identity problems in the "narrow world", in which people, exhausted with constant life tests, volatility, dynamics and changeability of positions, look for someone to blame for their problems, tawdriness and complexes (Bauman, 2004, pp. 13-40).

In my opinion, supranational communal competence is associated with the need to revitalize heterology, the study of the Stranger, to provide opportunities for expansion of civic participation in socio-cultural and political life in the conditions of natural cultural diversity beyond the boundaries of national states. (Nikitorowicz, 2016, pp. 11-23). Jacek Raciborski (2011, pp. 50-51) points out that in Europe "...we build the collective 'us' not only as members of civic communities but as people belonging to particular nations". As argued by William B. Gudykunst and Young Yun Kim (2002, pp. 525-527), communication with people from other cultures involves confrontation with languages, principles and standards different from ours. This confrontation may be the source of knowledge of the rules and standards of our own culture, which is, on the one hand, the source of frustration, and on the other hand, of gratification. The existence of cultural differences makes us aware of the need for communication, because we may not simply assume that the differences are a barrier to effective communication. One of the main factors determining the effectiveness of communication with the representatives of other cultures is our ability to understand them, which is impossible if we adopt an ethnocentric attitude.

Analyzing the functioning of the Commonwealth, historians point to a centuries-long multicultural experiment, which can be compared to the present situation in many Western European countries. This arouses questions about periods and determinants, about how long and on what conditions the host communities in the past and nowadays wanted to communicate with the newcomers, whether the idea, principles and policy of multiculturalism involved respect to and acknowledgement of their diversity, what were the principles, methods and forms of implementing it and what could be effective in our times. The main problem seems to be the fear of whether the previous dialogue and communal dimension of those bonds that are developed bonds will not be devalued or devastated. In the Commonwealth the newcomers from other ethnic or religious groups were not regarded as a threat; the hosts were not afraid of being dominated and did not perceive it as a danger for the ruling class. What mattered was whether the new ones were useful for the state and its inhabitants. "Jews were useful because of their knowledge of commerce and financial operations, 
just like Crimean Karaites and Armenians. In the case of Tatars or Karaites, military reasons predominated, while in the case of Germans, their economic competence.

It was similar in the Early Modern period: Mennonites had unquestioned competence in irrigation, Italians in economy, diplomacy, and, obviously, artistic culture, whereas Scots had military competence and also filled the gap in internal commerce". In the Commonwealth, religious tolerance for the noble class was one of the basic system principles. Religious differences could develop and be a factor binding particular ethnic groups (Jews, Mennonites, Armenians, Tatars). They adopted and used the official language while remaining distinct in other aspects. The multi-ethnic and multi-religious Commonwealth was united by one ruler. When forming the federal state, the king consulted with the representatives of different classes, not expecting them to renounce their culture or customs.

In the introduction to the work "Under a Common Sky: Ethnic Groups of the Commonwealth of Poland and Lithuania", Kopczyński writes about the Commonwealth as a state without stakes. He emphasizes the religious tolerance within it, which was a unique thing in Europe of the 16th century. A special value of the work in the context of cross-cultural education is the analysis of three groups: local, long-settled nations, newly-settled ones, i.e., immigrants coming to the territory of the Commonwealth in the Middle Ages, even before the state covered Lithuania and Ruthenia (Germans, Jews, Tartars, Armenians, Gypsies and Karaites), and newcomers, i.e., foreigners coming in the $16^{\text {th }}$ and $17^{\text {th }}$ centuries to look for better living conditions (Scots, Italians, Dutch Mennonites).

In the context of the foregoing, I consider it to be a significant task of cross-cultural education to analyze the historical experiences of the Commonwealth of many nations, to learn and use those experiences in order to understand the contemporary problems of the coexistence of cultures. It is a civic responsibility to continuously reflect on why in the awareness of free citizens of the Commonwealth the Polish-Lithuanian Commonwealth was never transformed into a Commonwealth of three nations. The idea did exist, but the Treaty of Hadiach from 1658 was signed too late. Perhaps this is the reason why contemporary Ukrainians tend not to refer to those traditions but to the inter-war period. Cossacks tried to rule their small hetman state on the left bank of the Dnieper river like the nobility of the Commonwealth did. Why were Cossacks not granted the nobility status as they wanted? What would the history of the Commonwealth have been if the Cossack elders had been granted noble rights in accordance with the status of "free and knightly people"? Was it possible to transform the Commonwealth into a trialist state including the people inhabiting the current Ukraine, and if so, when was it possible? Why were the growing number of Cossacks, their awareness and ambitions ignored? Why were all the social, religious and economic religions not taken into consideration and why was it thought that another cruel 
pacification of uprisings would cause peace and make the old order return? Fratricidal fights destroyed the pursuit of coexistence in thinking and action and led to the collapse of the Commonwealth. Since the middle $18^{\text {th }}$ century, the state was increasingly dependent on powerful neighbors and its autonomy was shattered.

$* *$

In the context described above, the challenge vested in cross-cultural education is to form and realize the essence of tradition of civil liberties and the relationships between liberty and free people and communities. When people and countries are free to organize without external pressures, they often try to use new, interesting solutions. We should highlight these inspirations and models, as well as the utterances of Polish citizens of Jewish origin expelled in 1968 (Wiszniewicz, 2008). This approach has been facilitated by numerous European Union programs and projects, such as SOCRATES, ERASMUS, Leonardo da Vinci and many others. Studying in another country contributes to the acquisition of linguistic and cultural competence, makes young people sensitive and teaches them to communicate in multicultural conditions. Thus, cross-cultural competence prompts the extension of the individual's potential, increases their resources and opportunities, develops the need to be free from existing divisions and helps eliminate stereotypical thinking. Gaining and developing competence is also related to the category of "resistance", preventing marginalization, exclusion and stigmatization, protecting and defending the right to self-determination, ensuring freedom and responsibility for the development of mankind and maintaining peace. To sum up, cross-cultural competence includes a set of competencies that enable mutual dialogue within a multicultural community. Hence, I have focused on cognitive competence.

I believe that knowledge and awareness of similarities and differences between nations is necessary. We need to know how to interpret historical, socio-political, psychological, geographical and other contexts; we need open-minded attitudes that eliminate prejudice, implicate insight, tolerance and communication readiness. One of the important research fields within supranational communal competence is education for teachers, who must be prepared to serve the role of cross-cultural mediators fostering the desire to learn about others and the ability to understand one's own culture and identity, approach the existing stereotypes with due distance and be able to recognize metaphoric meanings and cultural symbols.

Therefore, research and methodological monographs concerning the formation of cross-cultural communication competence in the process of learning Polish as a foreign language by children from other countries are really valuable. One of them is the monograph by Anna Młynarczuk-Sokołowska and Katarzyna Szostak-Król (2016), presenting the learning of Polish by children of various nationalities. Many Polish universities have projects preparing teachers to work as cross-cultural mediators as part 
of compulsory and optional classes, as well as initiatives carried out in collaboration with non-governmental organizations and institutions. The classes have the form of workshops, lectures and seminars combining subject-matter elements (providing knowledge necessary to live/work in multicultural environments) with elements of awareness development, practical skills and attitudes.

In my opinion, we should act with consideration of the well-known and recognized "humanistic coefficient" by Florian Znaniecki, focusing on the process of social and cultural change in categories introduced by Znaniecki: organization, disorganization and reorganization. It was assumed that rapprochement, understanding and continuous dialogue would occur spontaneously, yet we can see with great intensity the lack of understanding, lack of dialogue in different spheres of public life, even threats of the return of the "cold war" and new international conflicts, which lead to frustration and even greater fear in individuals and nations. We can see the inability to communicate with and understand each other among the representatives of different cultures, religions and denominations. The dialogue between humans and their natural environment is also problematic, with a clear crisis of mediation between nature and culture, faith and science, or perception and interpretation of good and bad in a person.

Thus, an internal dialog with ourselves is important, like the one in The Little Prince by Antoine de Saint-Exupéry. The dialogue led to the realization of insufficiency, to the discovery that my internal planet will not help me develop if I stay on it. Yet, I do not reject it, I cultivate the inherited values, care for them and respect my traditions. People who are the most important for me, symbolized by the rose, are on this planet and I care for them. But what is essential is the Little Prince's awareness that his own planet cannot concentrate on him only, because it blocks his development. Hence the decision to leave it so as to meet the strangers. With awareness that we can improve in contact with other planets if we learn to take the responsibility for others, develop bonds, and continuously build new communities. then, we will be able to ensure security to a higher number of planets and build mutual trust.

\section{References}

Bauman, Z. (2004). O tarapatach tożsamości w ciasnym świecie. In W. Kalaga (Ed.), Dylematy wielokulturowości. Kraków: Universitas.

Bauman, Z. (2011). Kultura w płynnej nowoczesności. Warszawa: Narodowy Instytut Audiowizualny.

Brotto, F., Huber, J., Karwacka-Vogele, K., Neuner, G., Ruffino, R., \& Teutsch, R. (2014). Kompetencje międzykulturowe dla wszystkich. Przygotowanie do życia w różnorodnym świecie. Council of Europe, Warszawa: Ośrodek Rozwoju Edukacji.

Buber, M., (1993), Problem człowieka. Trans. J. Doktór, Warszawa: PWN. 
Gajek, K., (2011)., Kompetencje międzykulturowe jako element kultury współczesnej organizacji - dylematy teorii i praktyki. Problemy Zarządzania, Vol. 9, 2 (32), 205-220.

Gudykunst, W.B., \& Kim, Y.Y. (1997). Communication with Strangers: An Approach to Intercultural Communications. New York: Mc Graw-Hill Education.

Gudykunst, W.B., \& Kim, Y.Y. (2002). Komunikowanie się z obcymi: spojrzenie na komunikację międzykulturową. In J. Steward (Ed.), Mosty zamiast murów. Podręcznik komunikacji interpersonalnej. Trans. J. Doktór. Warszawa: PWN.

Młynarczuk, A., \& Szostak-Król, K. (2016). Zrozumieć Innego. Międzykulturowa kompetencja komunikacyjna w procesie uczenia sięjęzyka polskiego jako obcego. Białystok: Fundacja "DIALOG".

Młynarczuk-Sokołowska, A., Potoniec, K., \& Szostak-Król, K. (Eds.), (2011). Przygody Innego. Bajki w edukacji międzykulturowej. Białystok: Fundacja Edukacji i Twórczości, Fundacja Uniwersytetu w Białymstoku.

Nikitorowicz, J. (2009). Edukacja regionalna i międzykulturowa. Warszawa: Wydawnictwa Akademickie i Profesjonalne.

Nikitorowicz, J. (2018). Etnopedagogika w kontekście wielokulturowości i ustawicznie kształtującej się tożsamości. Kraków: Impuls.

Nikitorowicz, J. (2016). Potrzeba rewitalizacji w przestrzeni życia społecznego znaczenia heterologii i kosmopolityzmu. In T. Sosnowski, W. Danilewicz, \& M. Sobecki (Eds.), Pedagog jako animator w przestrzeni życia społecznego, (pp. 11-23). Toruń: Wyd. Adam Marszałek.

Kopczyński, M. (2010). Introduction. In M. Kopczyński, \& W. Rygielski (Eds.), Pod wspólnym niebem. Narody Dawnej Rzeczypospolitej. Warszawa: Wyd. „Bellona”.

Kopczyński, M., \& Rygielski, W. (Eds.), (2010). Pod wspólnym niebem. Narody Dawnej Rzeczypospolitej. Warszawa: Wyd. „Bellona”.

Rachuba, A. (2010). Litwini. In: M. Kopczyński, \& W. Rygielski (Eds.), Pod wspólnym niebem. Narody Dawnej Rzeczypospolitej. Warszawa: Muzeum Historii Polski, Wyd. „Bellona”, Warszawa 2010.

Raciborski, J. (2011). Obywatelstwo w perspektywie socjologicznej. Warszawa: PWN.

Saint-Exupéry de, A. (1943). The Little Prince. Reynal \& Hitchcock: USA.

Wiszniewicz, J. (2008). Życie przeciętne. Opowieści pokolenia marca. Wołowiec: Wyd. "Czarne". 